\title{
Teacher Training and Pre-service Primary Teachers' Self-Efficacy for Science Teaching
}

\author{
Chantal Velthuis $\cdot$ Petra Fisser $\cdot$ Jules Pieters
}

(C) The Association for Science Teacher Education, USA 2013

\begin{abstract}
This study focuses on the improvement of pre-service teachers' selfefficacy for teaching science by including science courses within the teacher training program. Knowing how efficacy beliefs change over time and what factors influence the development by pre-service primary teachers of positive science teaching efficacy beliefs may be useful for teacher training universities, so that they can adapt their curriculum to accommodate these factors. Participants included 292 pre-service primary teachers, a cross-sectional sample from two different universities in the Netherlands across the four different years of study in the training program. Based upon our results, we conclude that the science teaching self-efficacy of pre-service teachers, in particular, improved during years 1 and 2, and not during years 3 and 4 . Higher levels of self-rated subject-matter knowledge and science teaching experience in primary schools both contributed to higher levels of personal self-efficacy for science teaching. Differences at the university level in courses taken during the first year between science content courses and science methods courses also influenced the pre-service teachers' development of science teaching self-efficacy. After their first year, the pre-service teachers from the university with science content courses had significantly higher self-efficacy than pre-service teachers from the university that offered science methods courses. After the second year of teacher training, however, this difference in self-efficacy was no longer present.
\end{abstract}

C. Velthuis $(\bowtie)$

Bachelor Teacher Training, Saxion University of Applied Sciences, PO Box 568, 7550 AN Hengelo,

The Netherlands

e-mail: velthuis@edith.nl; Chantal.velthuis@edith.nl

P. Fisser

SLO, National Institute for Curriculum Development, Enschede, The Netherlands

J. Pieters

Department of Curriculum Design and Educational Innovation, Faculty of Behavioral Sciences, University of Twente, Enschede, The Netherlands 
Keywords Teacher education · Pre-service primary teachers · Self-efficacy ·

Science teaching

\section{Introduction}

The Dutch universities that train primary teachers prepare pre-service teachers to teach children from 4 to 12 years old in all subjects, including science. The teacher training program takes 4 years, and the pre-service teachers are expected to acquire subject-matter knowledge and pedagogical knowledge for mathematics, language, the arts, history, science and all other subjects taught in the primary schools. A central challenge for primary teacher training universities is to develop a training program that prepares the pre-service teachers to become teachers with high teaching efficacy in all subjects. Unfortunately, we know from the TIMMS study (Trends in International Mathematics and Science Study) that only $27 \%$ of Dutch teachers feel confident about teaching science in the primary school, and that primary teachers even consider science to be less important than language or mathematics (Martin, Mullis, \& Foy, 2008). Dutch teachers spend only an average of 30-45 min per week on science education in grade 4, which is less than many other countries, including Hungary, Singapore, England, Japan and Italy (Martin et al., 2008). In addition, the amount of learning by inquiry during science lessons is less in the Netherlands than in the aforementioned countries (Meelissen \& Drent, 2008). This study aims to improve the preparation provided by the science coursework within teacher training programs by focusing on increasing the science teaching self-efficacy of pre-service teachers. Science teaching self-efficacy is important because a high sense of science teaching self-efficacy has been associated with teachers' lasting interest in science, a positive desire to help students and the willingness to improve science teaching (Bandura, 1997; Ramey-Gassert, Shroyer, \& Straver, 1996; Tschannen-Moran \& Woolfolk Hoy, 2007). Knowing the factors that influence the development by preservice teachers of positive science teaching efficacy beliefs and how efficacy beliefs change over time may be useful for teacher training universities, in order to adapt their curriculum to take these factors into account.

\section{Theoretical Framework}

\section{Self-Efficacy}

Teachers' sense of self-efficacy for teaching is a powerful predictor of their behavior in the classroom. Self-efficacy is defined by Bandura (1977) as one's perceived ability to perform an action that will lead successfully towards a specific goal. Teachers with a high sense of self-efficacy for teaching will set higher goals, be less afraid of failure, and find new strategies when old ones fail (Bandura, 1977; Tschannen-Moran \& Woolfolk Hoy, 2007). Bandura (1977) described two components of self-efficacy: personal science teaching efficacy and outcome expectancy. Personal science teaching self-efficacy is the belief in one's ability to perform the behavior and outcome expectancy is the belief that the behavior will 
lead to desirable outcomes. Self-efficacy is commonly understood as domain- and context-specific; one can have different levels of self-efficacy beliefs in different domains or for particular situations of functioning. Teachers' self-efficacy beliefs may vary from subject to subject, so that a teacher with high self-efficacy for teaching mathematics might not have the same high self-efficacy for science teaching (Bandura, 1977).

\section{Sources of Increases in Self-Efficacy}

According to Bandura (1997), people's beliefs about their self-efficacy can increase based upon four main sources of information. Mastery experiences are the most effective way of creating a high feeling of self-efficacy, and the more successful the experience, the more likely it is that one will repeat or extend that behavior. Vicarious experiences, which are observed examples or experiences undergone by others who are similar to oneself, can also increase the sense of efficacy: 'if they can do it, I can, too'. The third source of information that influences people's beliefs that they have what it takes to succeed is what Bandura calls 'social persuasion', or being persuaded verbally by others that one possesses the capabilities to master given activities. The final source of information that can increase self-efficacy is a reduction in people's stress reactions, which has to do with physical and psychological aspects and how these aspects are perceived and interpreted. One's mood affects one's judgements of self-efficacy.

Apart from the sources of increases in self-efficacy as described by Bandura, the amount of 'science' content knowledge or subject matter knowledge (SMK) is an important predictor for science teaching self-efficacy, particularly for personal science teaching self-efficacy. High science knowledge scores correspond with high personal self-efficacy scores for teaching science (Rohaan, Taconis, \& Jochems, 2012; Schoon \& Boone, 1998).

\section{Pre-service Teachers' Science Teaching Self-Efficacy}

For those who train teacher, the crucial question is how to prepare pre-service teachers for science teaching; in other words, what is the best way to enhance the science teaching self-efficacy of pre-service teachers in teacher training programs. Science education research reveals that various factors associated with science courses contribute to science teaching self-efficacy, both science methods courses and science content courses (Bleicher \& Lindgren, 2005; Cantrell, Young, \& Moore, 2003; Palmer, 2006; Schoon \& Boone, 1998; Settlage, 2000). The difference between science methods courses and science content courses is the aim of the course; science methods courses aim to instruct pre-service teachers on the skills needed to teach science, such as relevant teaching strategies, assessment of students' science knowledge and application of classroom management techniques, while science content courses aim to instruct them about science itself.

Science methods courses can have a positive impact on self-efficacy for teaching, especially when the program takes into account the four main influences on selfefficacy (Cantrell et al., 2003; Settlage, 2000). Settlage (2000) measured self- 
efficacy for teaching before and after participation in a methods course. The main purpose of the methods course was to teach teachers a new instructional approach. Both personal science teaching efficacy and outcome expectancy increased significantly. Preparing and teaching science lessons also seems to be an important element in the science methods courses, as demonstrated by Cantrell et al. (2003). The time spent on science teaching in a primary school or mastery experiences was associated with increases in pre-service teachers' personal science teaching selfefficacy during this course.

Other studies demonstrated the importance of subject matter knowledge, or a good conception of science for increasing the science teaching self-efficacy (Schoon \& Boone, 1998; Rohaan et al., 2012; Yilmaz-Tuzun, 2008). However, simply increasing the amount of science content in their courses can have just little a effect on pre-service teachers science teaching self-efficacy belief (Moore \& Watson, 1999; Schoon \& Boone, 1998). A reason is that the holding of alternative conceptions of science interfere with learning (Nussbaum \& Novick, 1982). For these pre-service teachers, science may seem confusing or incomprehensible because their variant conceptions provide a faulty foundation for the formation of new insights.

For a full understanding of the concepts presented in the science content courses, pre-service teachers consider demonstration, hands-on activities, discussions and further explanations to be important factors (Bleicher \& Lindgren, 2005; Schoon \& Boone, 1998).

Palmer (2006) studied a science course having both purposes: teaching about instructional methods and content. This course did provide demonstrations, handson activities and examples of lessons, but not enactive mastery experiences, which is considered to be the most powerful source of increases in self-efficacy (Bandura, 1997). Without mastery experiences, significant increases in self-efficacy over the duration of the course were still observed by Palmer (2006). The pre-service teachers said that they gained confidence directly from success in understanding content and pedagogy, which implies additional sources that influence pre-service teachers' self-efficacy, namely cognitive content mastery and cognitive pedagogical mastery.

All of these studies were at the level of science courses and not at the level of a teacher training program to prepare teachers. Only Cantrell et al. (2003) studied whether or not science teaching self-efficacy beliefs changed over the course of three semesters. During the first semester, students attended a science content course in combination with an introductory methods course, during the second semester students attended an advanced methods course and a 3 week practicum experience and the third semester was their teaching experience. No significant differences were observed in outcome expectancy beliefs. However, scores on personal science teaching self-efficacy increased significantly; the effect size for semester 2 compared to semester 1 was 1.12 and semester 3 compared to semester 2 was .82 .

The teacher training program in the study of Cantrell et al. consist of both science content courses and science method courses to increase the science teaching selfefficacy of pre-service teachers. However, it could be that a teacher training program only consisting of science method courses, in which pre-service teachers 
have to develop lessons in authentic situations might be more valuable for increasing the self-efficacy, because it is known that developing lessons brings about deeper understanding of a topic and assists pre-service teaching in developing confidence that the lessons can be undertaken and accomplished (Woolfolk, 1993). In this study, two different teacher training programs will be compared, one with only science method courses and one with a combination of science content and method courses, to determine the most effective combination of courses in teacher training programs for increasing the science teaching self-efficacy of the pre-service teachers.

\section{Problem Statement and Research Question}

Science education in primary schools in the Netherlands needs to be improved (Meelissen \& Drent, 2008). More time should be spent on science education and teachers should use inquiry approaches for teaching science more often, which will yield better results for the children in the field of science (Martin et al., 2008; Meelissen \& Drent, 2008). Increased self-efficacy beliefs can result in more time spent on science in the classroom and the depth at which science is discussed with the children (Jarvis \& Pell, 2004). In this study we focus on two different Dutch teacher training programs for gaining insight in effective combinations in science courses within teacher training programs and into elements in the science courses that can be valuable for improving the science teaching self-efficacy of pre-service primary teachers. The study seeks to answer the following research questions:

1. What is the effect of teacher training on pre-service primary teachers' science teaching self-efficacy in the Netherlands?

2. How are self-rated SMK and frequency of science teaching related to the science teaching self-efficacy of pre-service primary teachers?

3. Are there any significant differences in science teaching self-efficacy scores between pre-service primary teachers from two different teacher education universities, and how do university-level differences in curriculum content and assessment of the pre-service teachers relate to other factors influencing science teaching self-efficacy (level of self-rated SMK and frequency of science teaching)?

\section{Methodology}

Participants

This study was conducted at two different universities in the Netherlands. Both universities are located in the eastern part of the Netherlands and enroll the same type of students: graduates from secondary education and students from vocational education who graduated as teacher assistants. About $15 \%$ of the sample population was male and ages ranged from 17 to 39 . Preparation to teach in primary schools in both universities involves four successive years of coursework in combination with 
Table 1 The distribution of participating pre-service primary teachers across years and universities

\begin{tabular}{lccccc}
\hline & Year 1 & Year 2 & Year 3 & Year 4 & Total \\
\hline University A & 67 & 22 & 16 & 29 & 134 \\
University B & 75 & 55 & 27 & 1 & 158 \\
Total & 142 & 77 & 43 & 30 & 292 \\
\hline
\end{tabular}

an internship. There is coursework related to all of the subjects taught in primary schools; just as for the other subjects, the coursework in science is intended. The major differences between the two universities are the content of the courses in the first year and how pre-service teachers are assessed after these courses. University A starts out with science methods courses that are assessed by practical assignments and a theoretical test, while University B mainly concentrates on science content that is assessed by theoretical tests in the first year. A total of 292 respondents were included in our cross-sectional analysis, divided over the two universities and the years of coursework. The questionnaire was distributed on paper in all year one and a part of the year two classes (1/3 of University A and 3/4 of University B, because not all year 2 teachers administered the questionnaires to their classes). The first and second year respondents in this study is therefore a reasonable reflection of the total population in both Teacher Universities. The respondents of year 3 and 4 do not represent the population completely, because of their different choices in specialization, their internships, and because these pre-service teachers were digitally approached to complete the questionnaire. The data were collected from the participants after they had completed the course year. Table 1 presents an overview.

\section{The Science Methods Courses}

The training programs at both universities are organized in a major/minor structure. The major is the basic program during the first 2 years, which prepares students in general for their future profession as a primary school teacher. The third and fourth years offer opportunities for specialization. Besides the training program at both universities, pre-service teachers also do an internship. During the minor program, the pre-service teachers must observe and teach lessons by themselves; during the third and fourth years, pre-service teachers have more responsibilities and must teach the children the educational program for a complete school day every week of the school year.

The program content at the two universities differs with respect to the science courses, especially in the first year. The science courses at University A are mainly methods courses, but they also aim to reinforce science content knowledge. There are two methods courses during the first year, one specifically about science education and one about environmental education. The lectures from the first course involve numerous examples of lessons that are relevant to primary classrooms, and cover topics from living nature (biology) and non-living nature (chemistry and physics). At the end of the course, the pre-service teachers must teach a science 
lesson themselves in the primary school. In addition, their pedagogical content knowledge (PCK) is assessed in a theoretical test. During the second course, students learn how they can use the school environment to teach children about science, history and geography. The students experience in the method courses how they have to teach science in the primary school by doing 'hands-on', inquiry based activities by themselves and subsequently by reflecting on the 'hands-on' activities they learn how they can teach those activities in the primary school practice.

The science courses at University B are science content courses during the first year. University B offers two science content courses, one focusing on knowledge of living nature and the other focusing on knowledge of non-living nature, technology, and research and design skills. The students do hands-on, inquiry based activities to improve their own knowledge base and design skills. The pre-service teachers at University B take two theoretical tests, which assess mainly subject matter knowledge.

During the second year, both universities offer pre-service primary teachers two science methods courses. At University A, pre-service teachers attend two advanced methods courses that are specific for science. For both courses, pre-service teachers must complete a practical assignment that assesses their teaching performance and a theoretical test. University B also offers pre-service teachers two methods courses. The first one is specifically about how to teach science. During this course preservice teachers learn about various examples of good practices, which they can try carrying out in the classroom with primary students. This course is comparable with the first year methods course at University A. However, the assessment at University B is only a theoretical test and does not include a performance assessment. The second course at University B is a combination of science and visual arts. Pre-service teachers learn how to teach science in combination with arts by reflecting on an hands-on activity: the construction of a musical instrument out of several different materials. The characteristics and the content of the program for the major in primary education at both universities are summarized in Table 2 .

There are also differences between the minor programs at both universities. At University A, pre-service teachers must specialize in the specific age of the children they want to teach. This choice also determines the subject matter in which they will specialize. One of the possible specializations is science for younger children. At University B, pre-service teachers can specialize in a subject matter, for example, biology or technology, regardless of the age of the children they want to teach.

\section{Instruments}

The STEBI-NL (Fisser, Ormel, \& Velthuis, 2010) was used to measure science teaching self-efficacy of the pre-service teachers from years 1,2, 3 and 4 of the training programs. The STEBI-NL was translated from an existing, commonly used English instrument: the STEBI-A (Science Teaching Efficacy Belief Instrument), an instrument based on Bandura's self-efficacy theory that specifically aims at the beliefs of (pre-service) teachers about science in teaching and learning (Bleicher, 2004; Bursal, 2010; Riggs \& Enochs, 1990). The instrument intends to measure the self-efficacy of pre- and in-service elementary teachers with two scales: Personal 


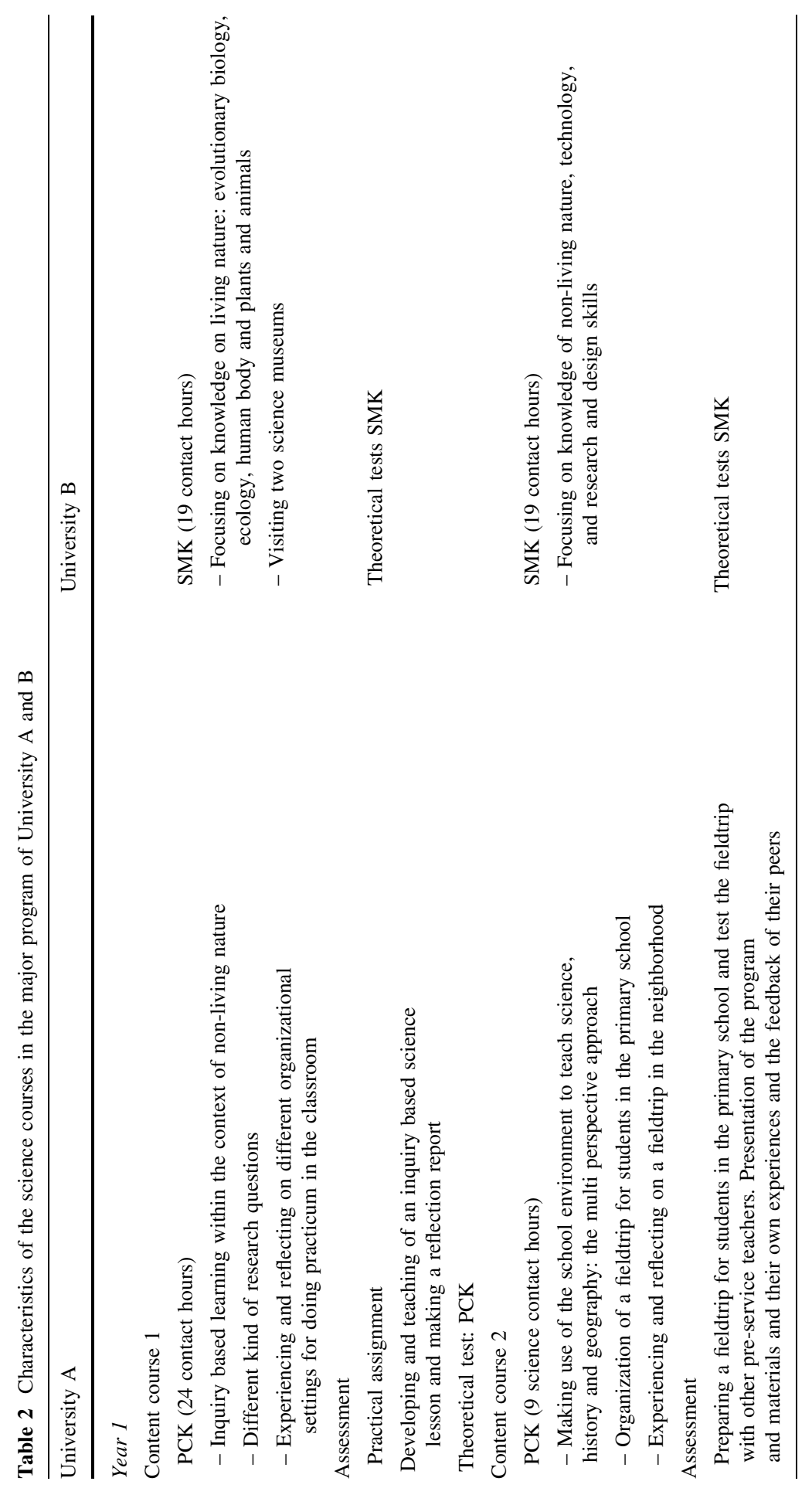




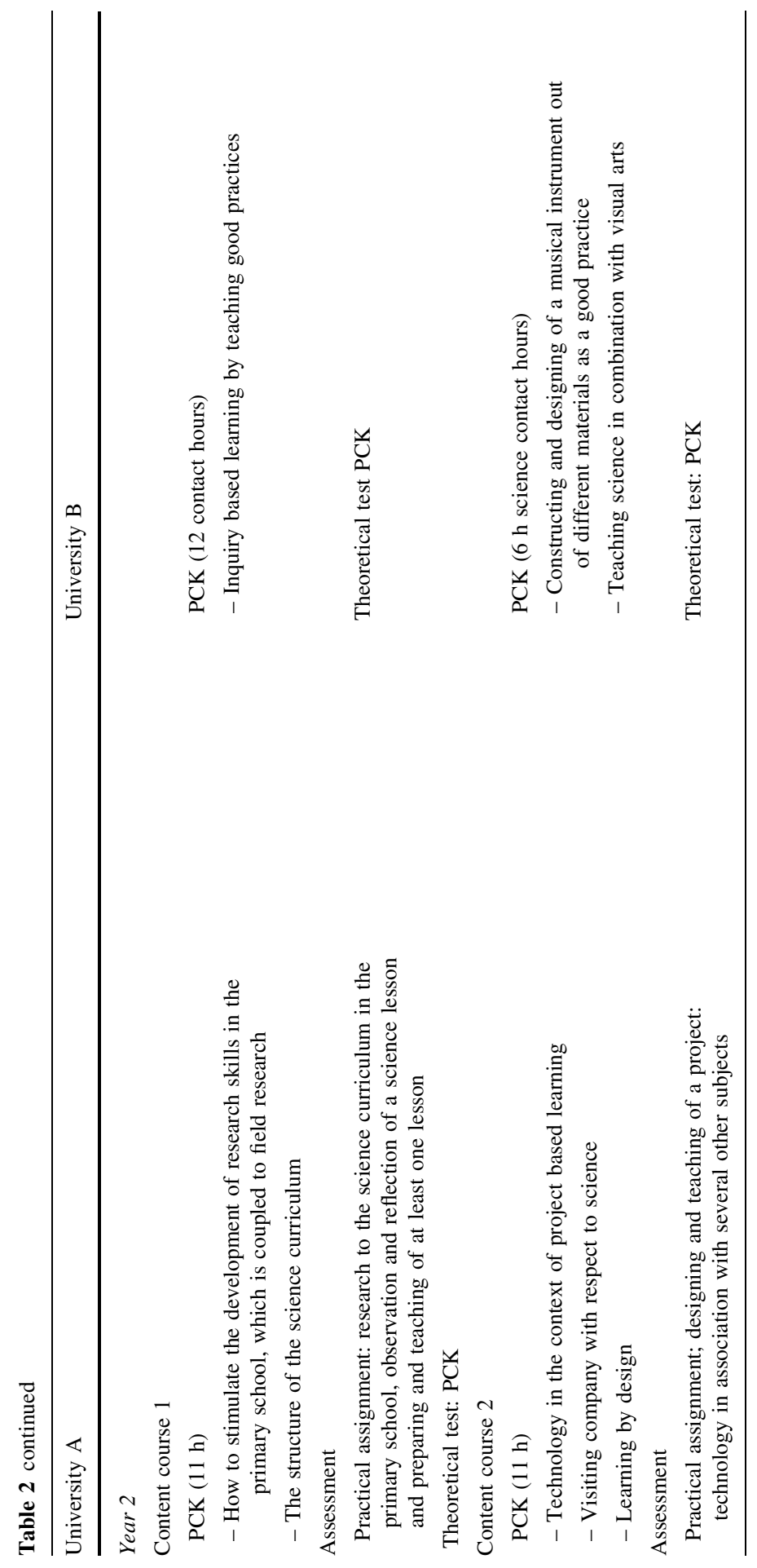


Science Teaching Efficacy (PSTE, self-assessment of one's teaching competence) and Science Teaching Outcome Expectancy (STOE, teachers' expectations that teaching can influence student learning). Enochs and Riggs made two versions, version A for elementary teachers (Riggs \& Enochs, 1990) and version B for elementary pre-service teachers (Enochs \& Riggs, 1990). The difference between these two is the tense of the items, present tense being used for the teachers and future tense for the students. In this study, we used the translated version of the STEBI-A, because pre-service teachers in this study do teach primary school students from year 1 and our interest was in the current self-efficacy of these preservice elementary teachers. The STEBI-NL is a 23 -item instrument, containing items such as, "I am able to answer students' science questions" (PSTE-12 items total) and "Increased effort in science teaching produces little change in some students' science learning" (STOE-11 items total). The pre-service teachers used a 5 -point Likert scale, ranging from strongly agree (5) to strongly disagree (1), to indicate their opinions on the statements. Negative items are reverse-coded and item-scores are summed to get the score for each scale. A higher score indicates a higher self-efficacy. Pre-service teachers, who did not score all the items were excluded from the results. Fisser et al. (2010) showed that the reliability for the PSTE scale was very good, with a Cronbach's $\alpha$ of .86. The reliability of the STOE scale was unacceptable, with a Cronbach's $\alpha$ of .56. In this study, only the PSTE will be used for analysis, and because of the low reliability $(<.6)$, the results for the STOE scale will not be further analyzed.

Secondly, additional questions were asked of the pre-service teachers to determine the relation between self-rated knowledge and self-efficacy, and the relation between frequency of science teaching experiences and science teaching self-efficacy. The questions are: (1) To what extent (insufficient-1/sufficient-2/ good-3) do you feel that you have the subject knowledge to teach science within living nature (biology), non-living nature (physics and chemistry) and technology; and (2) To what extent (often/a few time/not) have you already taught science in the primary school? The same questions are also used to see how differences in content and assessment in primary teacher education programs relate to the level of selfrated SMK and frequency of science teaching, the possible factors influencing science teaching self-efficacy.

\section{Results}

General Outcomes on Self-Efficacy Beliefs

Due to the low reliability of the STOE scale and high reliability of the PSTE scale of the STEBI-NL, we report only on the results for the latter scale. Table 3 shows the mean PSTE scores by years of teacher training, where the possible minimum score is 12 and maximum score is 60 . The mean PSTE score after 1 year of teacher training is 37.96 (5.06) and reaches its maximum after 2 years: 42.86 (5.82). During the third and fourth year the mean PSTE score of pre-service teachers slightly 
Table 3 Mean PSTE scores by years of teacher training

\begin{tabular}{lrll}
\hline Years of teacher training & $\mathrm{N}$ & PSTE Mean & $\mathrm{SD}$ \\
\hline 1 & 139 & 37.96 & 5.06 \\
2 & 76 & 42.86 & 5.82 \\
3 & 41 & 41.24 & 7.33 \\
4 & 30 & 41.07 & 5.56 \\
\hline
\end{tabular}

Table 4 PSTE scores of preservice teachers by self-rated SMK for teaching science

\begin{tabular}{lccc}
\hline & $\mathrm{N}$ & PSTE Mean & SD \\
\hline Self-rated SMK & for teaching & living & nature \\
Insufficient & 50 & 34.82 & \\
Sufficient & 179 & 40.56 & 5.36 \\
Good & 56 & 43.09 & 5.32 \\
Self-rated SMK for teaching & non-living nature & 6.09 \\
Insufficient & 149 & 37.51 & \\
Sufficient & 112 & 42.42 & 5.78 \\
Good & 24 & 44.75 & 4.93 \\
Self-rated SMK for teaching & technology & 5.33 \\
Insufficient & 174 & 37.90 & 5.60 \\
Sufficient & 97 & 43.06 & 4.92 \\
Good & 14 & 46.00 & 6.13 \\
\hline
\end{tabular}

decreases, but this decrease is not significant. These descriptive results can be interpreted as showing that pre-service primary teachers are slightly positive about their self-efficacy in relation to science teaching.

A one-way between-group analysis of variance (ANOVA) was conducted to explore the pattern of teacher training on PSTE. There was a significant difference in PSTE scores of pre-service teachers in the different years of teacher training $(F(3,282)=13.312 ; p=.000)$. Post hoc tests using Tukey's HSD showed that PSTE scores are significantly lower in year 1 than in any of the other years, but no other comparisons were significant.

\section{Self-Rated SMK Knowledge}

All pre-service teachers were asked to rate their own subject matter knowledge for teaching about living and non-living nature and technology as insufficient, sufficient or good. Cross-sectional descriptive statistics were calculated to analyze PSTE scores of pre-service teachers with a self-rated good, sufficient and insufficient level of science teaching SMK. The results are presented in Table 4.

There was a statistically significant difference in PSTE scores of the pre-service teachers with different self-rated levels of SMK for each of the three domains, living nature $(F(2,282)=32.121 ; p=.000)$, non-living nature $(F(2,282)=36.147$; $p=.000)$ and technology $(F(2,282)=37.383 ; p=.000)$. 
Table 5 PSTE scores of preservice teachers by their selfrated frequency of science teaching

\begin{tabular}{lcll}
\hline & $\mathrm{n}$ & PSTE Mean & SD \\
\hline Frequency of teaching science & & \\
Never & 113 & 36.81 & 5.12 \\
A few times & 132 & 41.52 & 5.40 \\
Often & 41 & 44.34 & 5.99 \\
\hline
\end{tabular}

Table 6 Tukey post hoc test for PSTE and the frequency of science teaching

\begin{tabular}{lllllll}
\hline $\begin{array}{l}\text { Dependent } \\
\text { variable }\end{array}$ & $\begin{array}{l}\text { (I) frequency of } \\
\text { science teaching }\end{array}$ & $\begin{array}{l}\text { (J) frequency of } \\
\text { science teaching }\end{array}$ & $\begin{array}{l}\text { Mean } \\
\text { difference } \\
(\mathrm{I}-\mathrm{J})\end{array}$ & Sig. & $\begin{array}{l}\text { Effect } \\
\text { size }\end{array}$ & $\begin{array}{l}\text { Cohen's } \\
\text { categories }\end{array}$ \\
\hline PSTE & Never & Often & $-7.536^{*}$ & .000 & 1.35 & Large \\
& Never & A few times & $-4.710^{*}$ & .000 & .90 & Large \\
& A few times & Often & $-2.826^{*}$ & .010 & .49 & Moderate \\
\hline
\end{tabular}

The results of the Tukey post hoc test indicate that there is a significant difference $(p=.000)$ in PSTE scores across all three domains between pre-service primary teachers with self-rated insufficient SMK and pre-service primary teachers with self-rated sufficient and good levels of SMK. The difference in PSTE between teachers with self-rated sufficient knowledge and teachers with good knowledge is only significant in the living nature domain $(p=0.008)$.

\section{Teaching Science}

All pre-service teachers were asked how often they have taught science in the primary school. The reason that pre-service teachers may have never taught science is because pre-service teachers do their internship mainly on a specific day during the week. If science is not on the program on that day, the pre-service teachers have to ask for a change in the schedule to be able to teach science or to perform their practical assignments. Cross-sectional descriptive statistics were conducted to analyze PSTE scores of pre-service teachers in terms of the frequency with which they have taught science (never, a few times or often). The results are presented in Table 5 .

There was a statistically significant difference in PSTE scores of the pre-service teachers with different levels of self-rated teaching frequency $(F(2.283)=38.495$; $p=.000$ ). The results of the Tukey post hoc test (Table 6) showed that pre-service teachers who had never taught science to children had significantly lower PSTE scores than those who had taught children a few times, while pre-service teachers who had taught science often had significantly higher PSTE scores than those who had taught only a few times or never. There is a larger effect size for the difference between never teaching science and teaching it a few times (1.35) than for the difference between teaching science a few times and teaching it often (.49). 


\section{Different Programs and Pre-service Teachers' Science Teaching Self-Efficacy}

An independent samples $t$ test was used to determine if there were significant differences between the two universities for teacher education with regard to the science teaching self-efficacy of their pre-service teachers during their major program (the first 2 years). As seen in Table 7, there is a significant difference in PSTE between students at the two universities after the first year of teacher training $(p<.05)$. Even though it is a small difference, it is a significant difference, which could imply that after 1 year, the pre-service teachers who participated in a science content course believe that they are more able to teach science compared to the preservice teachers who participated in a science method course. After 2 years of teacher training there was no longer any difference between the PSTE scores of the pre-service primary teachers from the two different universities.

The major difference between the training programs at University B and University A is the content of the first year science courses. University B mainly concentrates on SMK, while University A starts directly with pedagogical content knowledge. An independent samples $t$-test was conducted to compare the self-rated subject matter knowledge of the pre-service teachers from both universities after 1 and 2 years of teacher training. No significant differences were found between the self-rated SMK of pre-service teachers from University A and those from University B (years 1 and 2).

The self-rated SMK of the pre-service teachers at both universities increased significantly during the second year in two of the three domains, as shown in Table 8. At University A, the self-rated SMK of pre-service teachers after the second year was significantly higher in the domains of living and non-living nature, compared to that of the pre-service teachers after their first year. At University B, this was the case for the domains of living nature and technology. However, after completing the major program at both universities, second year pre-service teachers do not believe that their knowledge to teach about non-living nature and about technology science is sufficient (mean self-rated knowledge <2.00).

Science teaching is known to be an important factor for increasing science teaching self-efficacy and therefore cross-sectional descriptive statistics and independent samples $t$-tests were done for the frequency of science teaching by pre-service teachers at the two universities in their first 2 years. Contrary to our expectations, no significant differences were found in the self-rated science teaching frequency of pre-service teachers at University A compared to that of those at University B, after both 1 year and 2 years of teacher training.

If practical assignments did not result in pre-service teachers' perceiving that they were teaching science more frequently, we then questioned whether the practical assignments completed by student at University A might yield science teaching (mastery) experiences, which are more valuable for increasing science teaching self-efficacy than the more 'voluntary' science experiences of the preservice teachers of University B. An independent samples $t$ test was used to determine whether there was a significant difference in the science teaching selfefficacy of the pre-service teachers from University A who taught science just a few times compared to the same group from University B across the first 2 years. No 
Table 7 Independent samples $t$ tests (two-tailed) comparing mean PSTE scores for years 1 and 2 at Universities A and B

\begin{tabular}{lccccc}
\hline & $\mathrm{N}$ & Mean & $\mathrm{SD}$ & $d f$ & $p$ \\
\hline PSTE & & & & & \\
Year 1 & & & & & \\
$\quad$ University A & 65 & 36.86 & 5.16 & 137 & $.016^{*}$ \\
$\quad$ University B & 74 & 38.93 & 4.81 & & \\
Year 2 & & & & & \\
$\quad$ University A & 22 & 43.50 & 5.48 & 74 & .638 \\
University B & 54 & 42.59 & 5.98 & & \\
\hline
\end{tabular}

significant differences in PSTE were found between pre-service teachers who had taught science a few times, from the two universities. There were also no significant differences in PSTE found when comparing the pre-service teachers at the two universities who reported teaching science at the other two levels of frequency, never and often.

\section{Conclusions and Discussion}

This study focused on gaining insight into the elements in science courses within teacher training programs that are associated with improvements in the science teaching self-efficacy of pre-service primary teachers in the Netherlands. In this section, the conclusions will be described and the results will be discussed, in order of the main research questions. Then some general remarks will be made about the research design.

To answer the first research question regarding the effect of teacher training on pre-service primary teachers' science teaching self-efficacy in the Netherlands, the STEBI-NL was administered. From the results obtained, it can be concluded that the teacher training of pre-service primary teachers results in a significant increase in personal science teaching self-efficacy (PSTE) over the level at the end of the first year, but no significant differences in PSTE were found between any of the later program years. These results suggest that personal science teaching self-efficacy is improved primarily during the two-year major program of the teacher training till slightly positive. Because the pre-service teachers do have just a little teaching experience after 2 years, good beliefs about their personal science teaching selfefficacy cannot be expected. However, becoming more experienced with teaching during the minor stage does not result in an increase in science teaching selfefficacy belief of the pre-service teachers. The courses in the minor program seem not to have an impact on the science teaching self-efficacy, or it could also be that the minor courses prevent an 'implementation dip'. Several researchers have found an 'implementation dip' in self-efficacy as in-service teachers begin to implement their training in relation to a change initiative (Moseley, Reinke, \& Bookout, 2002; Ross \& Bruce, 2007). For example, Moseley et al. (2002) showed a significant drop in teachers' self-efficacy approximately 7 weeks after finishing training for professional development, when the teachers were back at their own schools to 
Table 8 Independent samples $t$ tests (two-tailed) comparing mean self-rated SMK for three science domains for years 1 and 2 at Universities A and B
*The difference is significant at the 0.05 level (2 tailed)

\begin{tabular}{|c|c|c|c|c|c|}
\hline & $\mathrm{N}$ & Mean & $\mathrm{SD}$ & $d f$ & $p$ \\
\hline \multicolumn{6}{|c|}{ Living nature } \\
\hline \multicolumn{6}{|c|}{ University A } \\
\hline Year 1 & 67 & 1.81 & .657 & 44.3 & $.045^{*}$ \\
\hline Year 2 & 22 & 2.09 & .526 & & \\
\hline \multicolumn{6}{|c|}{ University B } \\
\hline Year 1 & 74 & 1.89 & .563 & 127 & $.000 *$ \\
\hline Year 2 & 55 & 2.27 & .560 & & \\
\hline \multicolumn{6}{|c|}{ Non-living nature } \\
\hline \multicolumn{6}{|c|}{ University A } \\
\hline Year 1 & 67 & 1.42 & .581 & 87 & $.037^{*}$ \\
\hline Year 2 & 22 & 1.73 & .631 & & \\
\hline \multicolumn{6}{|c|}{ University B } \\
\hline Year 1 & 74 & 1.53 & .667 & 127 & .757 \\
\hline Year 2 & 55 & 1.56 & .660 & & \\
\hline \multicolumn{6}{|c|}{ Technology } \\
\hline \multicolumn{6}{|c|}{ University A } \\
\hline Year 1 & 67 & 1.33 & .533 & 87 & .111 \\
\hline Year 2 & 22 & 1.55 & .596 & & \\
\hline \multicolumn{6}{|c|}{ University B } \\
\hline Year 1 & 74 & 1.27 & .556 & 114.6 & $.047^{*}$ \\
\hline Year 2 & 55 & 1.47 & .573 & & \\
\hline
\end{tabular}

implement what they had learned. In the Netherlands, pre-service teachers teach lessons in primary school from the beginning of their teacher training; however, starting in the third year, pre-service teachers must teach the children the educational program every week for a complete school day. So, it might be that the pre-service teachers experience difficulty in translating what they have learned about science teaching at the university to the very busy educational program of the primary school where there are children with different needs. Tschannen-Moran and McMaster (2009) also demonstrated the difficulty of implementation for teachers by showing the importance for teachers' self-efficacy of coaching and assistance during implementation. For pre-service teachers, implementation is even more difficult because they are less experienced. Based on this result, one recommendation could be to assist and coach the pre-service teachers better when they begin taking on more responsibility for the educational program. This in itself is something for future research, because it raises the question of what the best way is to organize the coaching of the pre-service primary teachers. The science teacher from the university can coach pre-service teachers in the primary school, but another possibility would be to professionalise the teachers in the primary school so that they can assist and coach the pre-service teachers with the implementation on location. Professional development might be needed for in-service teachers, because those teachers had similar training at the teacher training colleges and might also have low science teaching self-efficacy. 
The second question to be answered in this study was: 'How are self-rated SMK and frequency of science teaching related to the science teaching self-efficacy of pre-service primary teachers?' Based on the results of the additional questionnaire and the STEBI-NL, we can conclude that higher levels of self-rated subject matter knowledge are related to a higher level of personal science teaching efficacy. There is a larger difference in PSTE between pre-service teachers with self-rated insufficient knowledge and those with sufficient knowledge than there is between teachers with self-rated sufficient knowledge and those with good knowledge. This result suggests that improving SMK in a science content course could be especially valuable when pre-service teachers believe that they have insufficient knowledge to teach science. When teachers believe that they already have sufficient knowledge to teach science, a content course might be less effective for raising levels of selfefficacy. This variation in PSTE differences related to the self-rated SMK levels of pre-service teachers might also explain the varying findings in literature. For example, both Schoon and Boone (1998) and Watters and Ginns (2000) showed that increasing the amount of science content resulted in very little effect on pre-service teachers' self-efficacy. On the other hand, both Rohaan et al. (2012) and YilmazTuzun (2008) showed the importance of subject matter knowledge for increasing the science teaching self-efficacy of pre-service teachers.

The second factor influencing science teaching self-efficacy observed in this study was the frequency of science teaching in the primary school. In line with Bandura's (1997) conclusion that mastery experience is the most important source of self-efficacy increases, we also found a positive relation between the frequency of science teaching and the PSTE of the pre-service teachers. The difference in PSTE is larger between pre-service teachers who never taught science and who taught science a few times than it is between pre-service teachers who taught science a few times and who taught science more often. This result suggests that the science teaching self-efficacy of pre-service teachers is increased mostly by their first teaching experiences in the classroom. Science teaching self-efficacy might continue to increase by teaching more science lessons; however, the effect seems to be less impressive. It could be that the experiences in the classroom become more 'normal' and become less effective for increasing science teaching self-efficacy. After a few science lessons, it might be that teachers are more aware of their own skills and knowledge levels and are also able to estimate better the reactions of the children in the classroom.

Another explanation could be that the pre-service teachers, who taught often science, had taught those lessons, with the help of textbooks and less by inquiry. When pre-service teachers reported to teach science frequently, science was not only taught in the context of the practical assignment, but it was on the program in the primary school. It could be that the pre-service teachers in this case had taught science in the way the primary school teacher normally does, so in a less innovative way with the help of textbooks. It seems therefore be important to challenge the preservice teachers to try new teaching strategies or to teach subjects they feel less comfortable with. Telling pre-service teachers that they can meet these challenges along with telling them to try them, is in line with Bandura's (1997) third source of self-efficacy, social persuasion. Those challenges could result in new, unexpected 
successes, which might result in increases in self-efficacy when pre-service teachers teach science often. Those challenges can be provided by the university; however, it might be better to professionalize the in-service teachers, so that they are capable to challenge the pre-service teachers. First, additional research to the quality of teaching is necessary to confirm that the pre-service teachers who received practical assignments from university teach in ways more consistent with professional expectations of high quality science.

The third aim of this study was to determine differences in science teaching selfefficacy scores between pre-service primary teachers from two different programs for teacher education. In addition, the relation between curriculum content and the level of self-rated SMK, and between the mode of assessment of pre-service teachers during the program and their perceived frequency of science teaching in the classroom was determined.

The main differences between the two universities are the content of the first year courses and how pre-services teachers are assessed after these courses. The main purpose of the science courses at University A was to teach the pre-service teachers how to teach science to primary children; therefore, they took two methods courses. At University B, the main purpose of the first year was to reinforce the pre-service teachers' content knowledge; therefore, those pre-service teachers took two science content courses. After 1 year of teacher training, the differences in curricula result in significant higher PSTE levels for students at University B. During the second year, the pre-service teachers at University A took two advanced methods courses and the pre-service teachers at University B also took two methods courses, although these were introductory. Even though there was a significant difference in the PSTE scores of the pre-service teachers when comparing the first and the second year of teacher training, there was no significant difference between the PSTE scores of the pre-service teachers from the two different universities. There were also no significant differences found between the self-rated knowledge of students from University A compared to students from University B after either year 1 or year 2 of teacher training. However, the self-rated knowledge of the pre-service teachers from both universities increased during the second year in every domain. This result indicates that pre-service teachers might perceive themselves to be learning SMK not only in science content courses, but also in the methods courses, which also aim to reinforce SMK by doing hands-on activities within the different science domains.

But overall the two different major programs of both universities do not lead to differences in science teaching self-efficacy nor to the self-rated knowledge levels. So, it seems that the content of the program during the first 2 years is not the reason for the low self-efficacy beliefs of the third and fourth year pre-service teachers. The reason for the low self-efficacy belief might be found in the third and fourth year of teacher education, because at that time the pre-service teachers have to translate what they have learned in university to the primary school practice. In many primary schools in the Netherlands, the teachers still rely on textbooks and structured materials (Meelissen \& Drent, 2008) instead of inquiry based learning; approaches to learning that are based on the investigation of questions, scenarios or problems. Thus pre-service teachers have to practice with inquiry based learning primarily in primary schools, where in-service teachers still judged science as not 
important enough to warrant finding additional time for it in the already overloaded curriculum (Platform Beta Techniek, 2010). To make it easier for the pre-service teachers to practice with inquiry based learning in the primary school, it might be important that in-service teachers become also aware of the importance of inquiry based science teaching and to increase also their science teaching self-efficacy. This implies that a combination of in-service teacher training and pre-service teacher training might result in a better environment for pre-service teachers to practice their science teaching, because the in-service teacher can coach the pre-service teacher with the translation of the theory about inquiry based teaching to the primary school classroom setting. This might result in more successes in the classroom, which is known to improve the science teaching self-efficacy (Bandura, 1997).

Furthermore, the relation between of the mode of assessing the pre-service teachers and the self-perceived frequency of science teaching was determined. At University A pre-service teachers are assessed by practical assignments and a theoretical test about PCK, while the pre-service teachers at University B are assessed only by theoretical tests, which are primarily about SMK in the first year and about PCK in the second year. In contrast to our expectations, no significant differences can be found between pre-service teachers at University A compared to pre-service teachers at University B in self-perceived science teaching frequency, after both 1 year and 2 years of teacher training. In addition, practical assignments for students at University A also did not result in more valuable science teaching experiences for increasing science teaching self-efficacy compared to the more 'voluntary 'science experiences of the pre-service teachers at University B. We can conclude from this result that practical assignments as a form of performance assessment do not contribute to the students' perception of having experienced more science teaching in the classroom. Science courses, methods or science content, in combination with an internship, as carried out at University B, seem to challenge pre-service teachers to teach science. Pre-service teachers might not need the additional pressure of a performance assessment. Despite there is no effect of the mode of assessment on the frequency of teaching, it would be very interesting for further research to investigate if there is a differences in the quality of teaching of the pre-service teachers as a result of the different mode of assessment.

A few critical remarks can be made regarding the methodology used in the presented study. First of all, this was a cross-sectional study, with science teaching self-efficacy measured at one time, with different participants in every group. A longitudinal, follow-up study at two universities is planned, to have more power in detecting long-term effects of differences in curricula on science teaching selfefficacy in the first year of science teaching. A longitudinal study, with hypotheses based on the current study, can strengthen our results and minimize the effects of extraneous variables, such as differences in science knowledge as result of prior education or gender.

To be able to measure both components of self-efficacy in the follow-up study, the STEBI-NL needs to be improved by clarifying the STOE items, but meanwhile taking care of the validity of the instrument by taken into account that the 
interpretation of the items remained the same as of the original items, only in an other cultural context.

With this study, we aimed to better inform teacher educators and to improve current pre-service primary teacher training for science teaching to be able to improve science teaching self-efficacy. Overall, to improve the teacher training program to increase the self-efficacy of the graduates of the teacher training University, the content of science courses in the major program, science content or science method, seems not to make a difference. More important is to improve the program from the third year, when students take the responsibility for the educational program and begin to translate of what they have learned about inquiry based science teaching in the primary school program. Creating a situation in the primary internship schools, which reflects better the theory educated in the teacher training programs, could make it easier for students to practice with science teaching and might result in an additional increase in science teaching self-efficacy also from the third year. Such a primary school situation might be created for example, by combining the pre-service teacher training with an in-service teachers training about the newest insights in science teaching. The in-service teacher is in this way, better able to coach the pre-service teacher with the translation of theory into the primary school practice, which might result in a better feeling of the preservice teachers about their science teaching. Another possibility to decrease the gap between theory and practice could be that the science teacher from the university is going to coach the pre-service teachers directly in the primary school. A third opportunity could be to give the pre-service teachers the assignment to redesign the textbook based curriculum to an inquiry based curriculum in collaboration with peers in the same internship school. By designing activities directly in the classroom situation, they might face and solve the problems with the translation of theory to practice in collaboration. Collaboration seems to be important especially for teachers with a low belief of teaching self-efficacy, because these teachers need ongoing encouragement and positive reinforcement (Ramey-Gassert et al., 1996).

The best way to improve the teacher training program from the minor stage is probably a combination of the above-mentioned solutions.

\section{References}

Bandura, A. (1977). Self-efficacy: Toward a unifying theory of behavioral change. Psychological Review, 84(2), 191-215.

Bandura, A. (1997). Self-efficacy: The exercise of control. New York: Freeman.

Bleicher, R. (2004). Revisiting the STEBI-B: Measuring self-efficacy in preservice primary teachers. School Science and Mathematics, 104(8), 383-391.

Bleicher, R. E., \& Lindgren, J. (2005). Success in science learning and preservice science teaching selfefficacy. Journal of Science Teacher Education, 16(3), 205-225.

Bursal, M. (2010). Turkish preservice elementary teachers' self-efficacy beliefs regarding mathematics and science teaching. International Journal of Science and Mathematics Education, 8(4), 649-666.

Cantrell, P., Young, S., \& Moore, A. (2003). Factors affecting science teaching efficacy of preservice elementary teachers. Journal of Science Teaching Education, 14(3), 177-192. 
Enochs, L., \& Riggs, I. (1990). Further development of an elementary science teaching efficacy instrument: A preservice elementary scale. School Science and Mathematics, 90(8), 694-706.

Fisser, P., Ormel, B., \& Velthuis, C. (2010). Natuur en techniek in het basisonderwijs: hoe bekwaam voelen de leerkrachten zich? [Science in the primary school: what is the science teaching selfefficacy of teachers?] . Paper presented during the Onderwijs Research Dagen, 23-25 june 2010. Enschede.

Jarvis, T., \& Pell, T. (2004). Primary teachers' changing attitudes and cognition during a two year science in-service programme and their effect on pupils. International Journal of Science Education, 1787-1811.

Martin, M. O., Mullis, I. V. S., \& Foy, P. (2008). TIMSS 2007 International Science Report. Findings from IEA's Trends in International Mathematics and Science Study at the Fourth and Eighth Grade. Boston: Boston College, TIMSS \& PIRLS International Study Center.

Meelissen, M., \& Drent, M. (2008). TIMSS-2007 Nederland: Leerprestaties in exacte vakken in het basisonderwijs [TIMSS-2007 the Netherlands: Science learning in primary schools]. Enschede: University of Twente.

Moore, J. J., \& Watson, S. B. (1999). Contributors to the decision of elementary education majors to choose science as an academic concentration. Journal of Elementary Science Education, 11(1), $37-46$.

Moseley, C., Reinke, K., \& Bookout, V. (2002). The effect of teaching outdoor environmental education on preservice teachers'attitudes toward self-efficacy and outcome expectancy. The Journal of Environmental Education, 34(1), 9-15.

Nussbaum, J., \& Novick, S. (1982). Alternative frameworks, conceptual conflict and accommodation: Toward a principled teaching strategy. Instructional Science, 11, 183-200.

Palmer, D. H. (2006). Sources of self-efficacy in a science methods course for primary teacher education students. Research in Science Education, 36(4), 337-353.

Platform Bèta Techniek. (2010). Technomonitor 2010. The Hague: Platform Bèta Techniek.

Ramey-Gassert, L., Shroyer, M., \& Straver, J. (1996). A qualitative study of factors influencing science teaching self-efficacy of primary level teachers. Science Education, 80, 283-315.

Riggs, I. M., \& Enochs, L. G. (1990). Toward the development of a primary teacher's science teaching efficacy belief instrument. Science Education, 74(6), 625-637.

Rohaan, E., Taconis, R., \& Jochems, W. (2012). Analysing teacher knowledge for technology education in primary schools. International Journal of Technology and Design Education, 22(3), 271-280.

Ross, J. A., \& Bruce, C. D. (2007). Professional development effects on teacher efficacy: Results of a randomized field trial. Journal of Educational Research, 101(1), 50-60.

Schoon, K. J., \& Boone, W. J. (1998). Self-efficacy and alternative conceptions of science of preservice elementary teachers. Science Education, 82(5), 553-568.

Settlage, J. (2000). Understanding the learning cycle: Influences on abilities to embrace the approach by preservice elementary school teachers. Science Teacher Education, 84(1), 43-50.

Tschannen-Moran, M., \& McMaster, P. (2009). Sources of self-efficacy: Four professional development formats and their relationship to self-efficacy and implementation of a new teaching strategy. The Elementary School Journal, 110(2), 228-245.

Tschannen-Moran, M., \& Woolfolk Hoy, A. (2007). The differential antecedents of self-efficacy beliefs of novice and experienced teachers. Teaching and Teacher Education, 23(6), 944-956.

Watters, J. J., \& Ginns, I. S. (2000). Developing motivation to teach elementary science: Effect of collaborative and authentic learning practices in preservice education. Journal of Science Teacher Education, 11(4), 301-321.

Woolfolk, A. E. (1993). Educational psychology. Needham Heights, MA: Allyn and Bacon.

Yilmaz-Tuzun, O. (2008). Preservice elementary teachers' beliefs about science teaching. Journal of Science Teacher Education, 192(2), 183-204. 